\title{
FEMALE ACCESS TO BASIC EDUCATION: A CASE FOR OPEN DISTANCE LEARNING (ODL)
}

\section{OFOEGBU I. Felicia PhD}

Senior Lecturer, Department of Educational Studies and Management

Faculty of Education, University of Benin, Benin City. Nigeria

\begin{abstract}
The purpose of this study was to investigate the impact of Open Distance Learning $(O D L)$ on the female access to basic education. The population of the study consists of all lecturers/teachers of ODL centres in Benin City, Edo State. Five ODL/Community Resource Study centres were identified and used for the study. The Lecturers responded to the "Female Education and Distance Learning Questionnaire" (FEDLQ). The validated and reliable (.76) instrument was used to collect data. The analysis of data revealed that ODL has significant influence on female enrolment and attendance. It showed that ODL will give girls a chance to catch up academically with their male counterparts who, unlike them, have every opportunity to attend school. The result of the study strongly recommends $O D L$ as a strategy for ensuring that girls enrol and attend school and consequently, fundamental to female economic opportunity. With ODL female children can have access to education at their convenience.
\end{abstract}

Key Words: Open Distance Learning; Basic Education; Access; Female,

\section{Introduction}

It is a well recognized and acclaimed statement that education is the most potent instrument for development and for mental and social emancipation (Ojo, Ogidan and Olakulehin, 2001). The analysis of access to basic education in Nigeria builds on the education policy of "free, compulsory and universal" basic education policy (Federal Government of Nigeria, FGN, 1999) and on the World Bank (2000) sector studies. While it is acknowledged that access to education has improved, it has also been observed that female access to education is excruciatingly slow. It has not grown fast enough to achieve the universal level of participation in primary and Junior Secondary schools.

Today, millions of school-age children do not ever enrol in school. Indeed an estimated 120 million children in developing countries do not attend any school at all and an additional 150 million of those who do enrol in school drop out before completing the four years necessary to develop sustainable literacy skills (UNESCO, 2003). In Sub-Saharan 
Africa, 40 percent of children (42 million) are out of school, 26 percent (46 million) in South Asia are not enrolled for primary education, and of those who enrol 33 percent do not complete in Sub-Saharan Africa, 41 percent in South Asia,.

Hence, the Eight Most Industrialized Countries in the World (G-8) endorsed the key international "Education for All" goals including the principle that no country with a strong national action plan to achieve universal access to primary education by 2015 should be permitted to fail for lack of resources (UNESCO, 2003). This has led to a new commitment by the World Bank (2003) to double lending for Basic Education in poor countries

In Nigeria, despite its free education policy (FGN, 2004) at all levels of schooling, access to education for all remains unattainable more so for girls and women UNICEF: (2002). Indeed in some Nigerian administrative states like Sokoto and Zamfara, the female literacy rate is as low as 12 percent when compared to 59\% for boys (UNESCO, 2003). The statistics indicated a wider gender disparity with $65.5 \%$ of males being literate as against $39.5 \%$ literate females. The same period revealed that of the nearly 7.3 million children of primary school age not in school about $62 \%$ were girls. In fact only about $33 \%$ and $28 \%$ of female children respectively attend primary and secondary schools in sub Saharan Africa. The low rate of female access to education is therefore not peculiar to Nigeria but applies to other countries in Sub-Saharan Africa. This could be generally as a result of negative challenges which include ineffective and inefficient implementation of the National Policy on Education (FGN, 2004) and reforms in the Nigerian education system, poor economy, poor management of scare resources and undemocratic governance (UNESCO, 2002). More importantly other negative factors which affect girls' education most are poverty, early marriage and teenage pregnancy, culture and religious issues, and gender bias in content, teaching and learning process. Consequently achieving education for the girl-child remains beyond the grasp of Nigeria and many developing countries of the world.

The international reports and conferences like Jomitien (1990) E-9 Education Ministerial Review Meeting in Beijing (2000) and the Dakar Education for All (EFA, 2000) recognize that unless girls' education is viewed with all seriousness and deliberate efforts made at ensuring that female children of school age are encouraged to attend and complete school, the disparity in gender enrolment and the international objective for education will hardly be achieved. 
It is against this backdrop that Open and Distance Learning (ODL) has been identified as the panacea to the perennial educational challenges of equitable access to learning, equality of basic educational opportunities as well as providing a second chance for women and girls who had never been or had once been in the system but had to dropout for one reason or another. Access implies the facilitation of people, in this case girls, to get education, the opportunity for enrolment as well as the facilitation and the encouragement of sustaining enrolment by learners in appropriate education programmes.

The essence of ODL teaching and training is that girls can take advantage of learning opportunities anytime, anywhere to implement positive change in their lives. Basic Education is referred to as

all forms of organized education and training That meet the basic learning needs of the individual including literacy and numeracy, general knowledge, skills, values and attitudes that is required to survive, develop capacities, live and work in dignity, improve quality of lives and make informed decisions and continue learning (UNESCO, 1997:7).

Basic education appears to be a retreat from the narrow concept of formal education. It views education in its broadest sense as a close articulation of the formal, non-formal and informal approaches to the structures for the awakening and all round development of the human capital. It recognizes that the formal schooling alone can no longer constitute the only organized educational experience for most school aged children and adults. This may be the reason several countries, including Thailand, 1940; Zimbabwe, 1967; Zambia, 1968; Uganda, 1972; Japan, 1984; and Germany, 1997 adopted and documented correlation between investment in Basic education and economic productivity, social development, and health awareness.

The Nigerian Basic education programme was launched in 1999. It is provided at the primary and the first three years of secondary school. From its development perspective, basic education responded to the official endorsement of Human Rights adopted by the United Nations in 1948 under the assertion that everyone has a right to education. Better access to Basic education through the Open and Distance Learning can therefore be a catalyst for female access to education, poverty reduction and a broader participation in the benefits of global economy integration.

The concept of Open and Distance Learning (ODL) meets the Capability Approach Theory which stresses any form of learning in 
which the provider enables the recipient to exercise choice of what they learn, how and where they learn and how quickly they learn to have their learning assessed. It emphasizes freedom to carry on working and schooling as long as one is capable. ODL is not a new concept. In Nigeria the history of ODL dates back to the late 1940s and 1950s, the era when correspondence education was a means of preparing candidates for the General Certificate of Education (GCE), which was a pre-requisite for the London Matriculation Examination.(Jegede, 2006; Moore and Tait, 2002).

Aderinoje and Ojokheta (2004) reported that Nigeria's original core of administrators and educators were products of the University of London distance learning without enjoying any formal ties to the university. Therefore Nigeria was not left out of the opportunities of ODL. But the delivery of the course content through a dynamic and interactive communication process as occurs at present seemed to have introduced it as a fairly recent innovation in education (Edmonds, 2006). The importance of the need for teaching and learning within and outside the school environment and the sudden rise in technological creativity in several developed and some under developed societies has brought Open Distance Education into limelight (Egwuasi, 2005). These learning trends indicate that less effort is needed to ensure access to education for all especially for girls who are socialized to be more domesticated and docile while boys are encouraged to learn.

A considerable number of studies have been carried out on ODL particularly in developed countries with concern for ensuring and meeting the needs of quality education for all including women. Peratton, Robinson and Greed (2001) define distance education as an educational process in which a significant proportion of teaching is conducted by someone far removed in space and/or in time from the learners. While open learning is viewed as an organized educational activity based on the use of teaching materials in which the constraints on study are minimized in terms of access, entry or time and place, pace, method of study or a combination of any of these; UNESCO (2002) equally stated that ODL represents approaches that focus on opening access to education and training provision, freeing learners from constraints of time and place and offering learning opportunities to individuals and group of learners.

Open Distance Learning is a system of education that uses modern communication facilities including high speed internet connection, computers, and CD-Rom. radios and television systems to facilitate learning process. Therefore the concept of ODL suggests an educational approach designed to reach learners in their homes, offices, shops, and study centres and provides, enough learning resources for 
them to qualify without attending formal classes. It is regarded as schooling without walls, extra mural studies, experimental learning, offcampus education, and open learning (Egwuasi, Etim and Obott, 2006). It creates opportunity for Life Long Learning, Life Wide Education, Adult Education, Mass and Media Education, Self Learning, Personalized Learning and Part-Time Studies. It prepares individuals for personal development and enhancement as they manage the challenges of schooling, living and working in a diverse, global society. Aderinoye and Ojokheta (2004) posited that there were positive links between the demand for education and the urge to be educated. Calvert (1986) asserted that ODL helped to extend the market for education to clients who had not been previously served with special attention. Hence Ofoegbu (2007) suggested that one of the ways to ensure that the demand for education conformed to growth in educational facilities was to ensure a well organized Open and Distance Learning system.

UNESCO (2002) posited that ODL was not necessarily the most cost efficient approach to education but it might be the only way to reach some target audience. In this context, lowering the cost of education may not be an objective of ODL. Thus, the objective of ODL is to enhance the opportunities that support education for all and life-long learning and at the same time provide avenues for the acquisition of qualitative education for all categories of learners especially women. Therefore Open Distance Learning in Nigeria is justifiable on several grounds which included that:

a) by 2015 all children, particularly girls and children in difficult circumstances and those belonging to ethnic minorities, have access to and complete free and compulsory primary education of good quality.

b) by 2015 fifty percent (50\%) improvement in the level of Adult education especially for women should be attained.

c) Gender disparities in primary and secondary schools are to be eliminated.

UNESCO (1997) states that though most ODL programmes were targeted at the adult population, for example the National Open University of Nigerian (NOUN), they could be used for school age children and youths who were unable to attend formal school system. But the conclusions from comparing ODL and conventional classroom 
performance in course contents appear ambiguous; while Maki, Maki, Patterson and Whittaker (2000), Poirier and Feldman (2004) reported advantageous examination outcome for ODL students, Waschull (2000) and Kinney (2001) stated that there was no difference in performance between ODL and formal classroom based students. Wang and Newlin (2000) on the contrary held the view that students in the conventional classroom setting performed better and had higher course grades than their ODL peers.

\section{Statement of Problem}

Female children, like male children, need quality education. But unlike male children several challenges which include poverty, cultural and economic issues, hinder the regular participation of the girl-child in education. Hence women and girls who constitute over $50 \%$ of the nation's population have been discriminated against and effectively denied education which is one of the fundamental human rights and a veritable tool for development and empowerment.

The female child is subjected to the indignation of child labour. When work relates to domestic and economic activities girls are more likely to be readily involved than boys in the acceptance of a low regular cash income. In this case parents are most likely to keep girls out of school. They are invariably streamed out of school for development into "schooling for subordination and marginalization". No development strategy is better than one that involves women as central players. It is a long term investment that yields exceptionally high returns. In response to such bias in education there is need to find out if Open Distance Learning (ODL) will give girls a chance to increase enrolment and attendance and subsequently catch up academically with their male counterparts.

\section{Research Question}

Ho1. Will ODL have significant influence on female access to basic education?

Hypothesis: The following hypothesis is formulated and tested at 5\% level of significance.

Ho1 ODL will not significantly influence female access to basic education. 
Ho2 There will be no significant difference among male and female teachers on the influence of ODL on female access to basic education.

Ho3 There will be no significant difference among experienced and inexperienced lecturers on the influence of ODL on female access to basic education.

The purpose of the study is to provide empirical evidence supporting the assumption that Open Distance Learning will improve female access to quality basic education. The essence of focusing on women and girls is to remind policy makers and educational managers that for many countries that have disadvantaged children and females, schooling remains physically and financially out of reach.

The study has significant implications for the nation's "sevenpoint agenda" and the endorsement of the G-8 commitment to the right of every citizen to basic education The findings will enable education planners and managers to ensure access to quality education for all particularly females through Open Distance Learning (ODL).

\section{Methodology}

Population

There are five government recognized Open Distance Learning/Community Resource Study centres in Benin City, Edo State. The population of the study consists of all the twenty-five lecturers teaching in the five (four private and one public) ODL centres. These lecturers (six female and nineteen male) were used as respondents to the instrument for the study.

\section{Instrumentation}

A validated and reliable (0.76) instrument entitled Female Education and Distance Learning Questionnaire (FEDLQ) was used to collect data. The questionnaire consisted of two sections. Section A of the instrument focused on the demographic information on the teachers. It sought to find out the gender of teachers and years of experience and ownership of the centres. Section B was constructed to generate data on the influence of Open Distance Learning on female access to basic education. This section was based on a four-point Likert scale. The highest attribute (04) indicated high effect of ODL on female access to basic education while the least attribute (01) indicated a situation where ODL had no effect. 


\section{Results}

The results of the study are shown in the tables below.

Ho1: ODL will not significantly affect female access to basic education based on ownership

Table 1: $\quad$ Effect of ODL on Female Access to Basic Education

\begin{tabular}{|l|l|l|c|c|c|c|}
\hline Teachers & No. & Mean & SD & t-calculated & Table value & Remark \\
\hline Public & 10 & 3.89 & $\mathbf{1 . 4 1}$ & .017 & 1.96 & NS \\
\hline Private & 15 & $\mathbf{3 . 8 8}$ & $\mathbf{1 . 4 6}$ & & & \\
\hline
\end{tabular}

$\mathrm{P}<.05$. Source: field work

The result of the analysis in Table 1 shows the calculated $t$-value of .017 , which did not exceed the table valve at .05 level of significance. It also shows that the calculated means of 3.89 and 3.88 are high. Therefore the null hypothesis which states that Open Distance Learning will not significantly influence female access to basic education is not accepted. The analysis concludes that ODL will significantly affect female access to basic education.

Ho2 There will be no significant difference among male and female teachers on the influence of ODL on female access to basic education

Table 2 T-tcst of significant difference on influence of ODL on Access to Education

\begin{tabular}{|l|l|l|l|l|l|l|l|l|l|}
\hline & \multicolumn{4}{|l|}{ Attdnce } & \multicolumn{3}{|l|}{ Retnt } & \\
\hline Variable & No & Mean & SD & t-cal. & Sig. & Mean & SD & t-cal & Sig. \\
\hline Male & 19 & 3.98 & 1.67 & \multirow{2}{*}{013} & NS & 3.85 & 1.9 & \multirow{2}{*}{.86} & NS \\
\hline Female & 6 & 3.88 & 1.68 & & & 3.87 & 1.5 & & \\
\hline
\end{tabular}

Not significant at $\mathrm{P}<.05$. Source: field work

Key: Attdnce $=$ Attendance, Retnt $=$ Retention;

The result of the analysis in Table 2 shows that the calculated $t-$ values of the variables (attendance, $\mathrm{t}$-test $=.013$; Retention $\mathrm{t}$-test $=.026$ ). The situation here is that male and female teachers are of the same opinion that ODL will significantly influence female attendance and retention at basic education. The hypothesis is therefore upheld. 
Ho3 There will be no significant difference among experienced and inexperienced ODL teachers on the influence of ODL on female access to basic education.

Table 3: $\quad$ Z-test Analysis of effect of ODL based on gender

\begin{tabular}{|l|l|l|l|c|c|}
\hline \multicolumn{1}{|c|}{ Variable } & No. & Mean & SD & $\begin{array}{c}\text { t- } \\
\text { calculate }\end{array}$ & Remark \\
\hline Experienced & 12 & 3.77 & 2.51 & \multirow{2}{*}{.018} & Not Sig. \\
\hline Inexperienced & 13 & 3.72 & 1.68 & & \\
\hline
\end{tabular}

$\mathrm{P}<05$. Source: field work

Table 3 above reveals that the calculated t-value.018. At 5\% level of significance the calculated $t$-value was not statistically significant. Therefore Experienced and Inexperienced teachers equally agree that ODL will significantly affect female access to basic education. The hypothesis is accepted.

\section{Discussion}

Nigerians cannot effectively develop Nigeria with the majority of its female population having no access to education. The study affirms that Open Distance Learning offers a solution for the perennial challenges of inequitable access to education. The findings correlate with those of Okoli (2006) who stated that ODL was a universal call to literacy. It upholds the assumption that the objective of the programme is to enhance the opportunities that support the Education for All (EFA) policy while at the same time providing avenues for the acquisition of basic knowledge and skills especially for women and girls (MDGs, 2000). The finding of the study reveals that even though most Open Distance Learning programmes were targeted at the adult population they could be conveniently adapted for children of school age who are unable to attend the formal conventional school system (UNESCO, 1997). Indeed one of the ways to ensure that demand for education was in conformity with growth and access to education is to ensure a well organized and managed ODL programme (Ofoegbu, 2007).

\section{Implication of Study}

The implication of the study is the creation of awareness in the mind of parents and guardians of the various ways the Government and voluntary organizations (NGOs) could provide basic education opportunities for those girls who must work for economic reasons. Such awareness will help them explore ODL as means of ensuring that their 
female children and wards can work and attend school at their own convenience to meet the objectives of basic education. The adoption of Open Distance Education delivery system in Nigeria is justifiable if only to expand and improve comprehensive early childhood care and education especially for the most vulnerable and disadvantaged children. The study should not be seen as supporting child labour but rather as a positive alternative to meeting demands and at the same time having access to education which will subsequently eliminate the obscenity of child labour.

\section{Conclusion}

The study concludes that ODL will give girls a chance to increase enrolment and attendance and subsequently catch up academically with their male counterparts. It will significantly affect positively female access to basic education.

\section{Recommendations.}

ODL is not a new concept for access to education in the Nigerian educational management. It has had a significant effect on the education of Nigeria's adult population in the early 1950s and 60s and recently with the establishment of the National Open University, Nigeria (NOUN, 2004). With the limited spaces in the formal conventional education systems there is need to identify other educational programmes which would enhance meeting the demand for basic education and subsequently eliminate gender disparities in primary and secondary education. It is therefore recommended that:

a) Government should support the establishment of Open Distance Learning centres for Basic Education with appropriate legislation.

b) Government should embark on literacy campaign for a period of ten years within which time frame all or most of the available resources will be mobilized towards achieving and ensuring female access to basic education.

c) Since Literacy begins at the lower rather than the higher levels of education with over 50 million Nigerians still illiterate while seven million children who are of school age are still not in school, Government, through the Ministry of Education, should establish a Commission for the ODL centres specifically meant for Basic Education. This would enable Nigeria attain the objectives of the Vision 2020. The status of the commission should be indicated in the National policy on education. .

d) ODL should be seen as a positive strategy for meeting the demands 
for education, an instrument for poverty alleviation and economic empowerment. Hence it has become necessary for Government and Non Governmental Organizations to organize and manage Open and Distance Learning programmes to meet the education for girls.

\section{References}

Ak'yeampong, K et al (2007) 'Access to Basic Education in Ghana: The Evidence and the Issues; Project Report, Consortium for the Research and Educational Access, Transition and Equity (CREATE) Falmer, UK and Winneba, Ghana.

Aderinoye, R and Ojokheta, K. (2004). Open and Distance Education as a mechanism for sustainable development: reflections on the Nigerian experience. International Review of Research in Open Distance Education. 5(1)33-40.

Okoli, A (2006) Problems of Distance Learning and Life Long Education: Implications for Management of Literacy Programmes in Nigeria Nigerian Journal of Educational Administration and Planning. 6(2)177- 189.

Dohmen, G (1967) Das Fernst Udium. Ein neves paidagogisches forsch ungsund arbeiteld. Tubingen: Diff.

Egunyomi, D (2007) Access to Basic Education for Girls: the Nigerian Experience.

Egwuasi, P. I. (2005) Open Distance Education in the 21sl century: structured or transactional for the Nigerian experience? Paper presented at the pre-retirement lecture in honour of Prof Mbong Udofot.

Egwuasi, P. I., Etim, P. J and Obott, J. F (2006). "Preference for Open Distance Learning for Enhanced Access and Balanced Development in the 21st Century Nigeria" Nigerian Journal of Educational Administration and Planning. 6, (2). 190 -203.

Federal Government of Nigeria (2002) Blueprint and Implementation Plan for The National Open University And Distance Learning Programme. Federal Ministry of Education, Abuja.

Jegede, O. J (2003) "taking the Distance out of Higher Education in the 21 $1^{\text {st }}$ Century Nigeria". An invited convocation lecture presented at the Federal Polytechnic, Oko, Anambra State.

Keegan, D (1982). Foundation of Distance Education $3^{\text {rd }}$ edition. Hagan: Ziff. Kinney, N. E. (2001). A guide to design and testing in online psychology courses. Psychology Learning and Teaching, 1, 16-20.

Maki, R. H., Maki, W. S., Patterson, M., and Whittaker, P. D. (2000). Evaluation of a web-based introductory psychology course. 
Learning and satisfaction in on-line versus lecture courses. Behaviour Research Methods, Instruments And Computers, 32. 230-239.

Moore, M and Tait, A (2002) Open and Distance Learning: Trends, Policy and Strategy Considerations. Paris, UNESCO.

Ofoegbu, F. I. (2007) "Matriculation related wastage in Nigerian universities". International Studies In Educational Administration (CCEAM), 35(2)51-65.

Ojo, D. O, Ogidan, A. M and Olakulehin, F. K (2006) Attitudes and perceptions of students to Open and Distance Learning in Nigerian. The International Review of Research in Open and Distance Learning, 7 (1) 24 - 36.

Poirier, C. R. and Feldman, R. S. (2004). Teaching in cyberspace: on-line versus traditional instruction using a waiting list experimental design. Teaching Psychology. 31. 59-62.

Rosenfelt, D. S. (1997) "Women's Studies, Multicultural Education And Curriculum Transformation In Policy And Practice In The United States". Women's Studies Quarterly. XXI1 (3\&4) $26-41$.

Subrahmanuan, R (2002). Class struggles: the challenges of achieving schooling for All. Id21 Insights

Tejuosho, F (2008) "Illiteracy is our biggest problem as women". Saturday Vanguard Neivspaper, March 22. p. 17.

UN1CEF: (2002), Human Development Index (HDI), UNDP Human Development Report.

UNESCO (1997) Adult Education in a Polarizing World Education for All Status and Trends. Forum Secretariat, France.

UNESCO (2002) Strategy for the Acceleration of Girl's Education in Nigeria. Federal Republic of Nigeria, Abuja.

Wang, A. Y. and Newlin, M. H.,(2000). Characteristics of students who enrol and succeed in psychology web-based classes. Journal of Educational Psychology. 92, 132-143.

Waschull, S. B.(2000). The on-line delivery of psychology courses: attrition, performance and evaluation. Teaching of Psychology. 28, 143-1

World Bank (2000) Educating Girls and Women: Investment in Education. Population and Human Development Resources Department Washington DC. 